\title{
Karakteristik Ekstrak Kulit Buah Kakao (Theobroma cacao L.) sebagai Sumber Antioksidan pada Perlakuan Ukuran Partikel dan Waktu Maserasi The Characteristics Extract Of Cocoa Pod Husk (Theobroma cacao L.) as A Source of Antioxidants in The Treatment of Particle Size and Maceration Time
}

I Putu Lingsan Pratyaksa, G.P. Ganda Putra*, Lutfi Suhendra

PS Teknologi Industri Pertanian, Fakultas Teknologi Pertanian, Universitas Udayana, Kampus Bukit Jimbaran, Badung, Kode pos : 80361; Telp/Fax : (0361) 701801.

Diterima 23 Oktober 2019 / Disetujui 08 November 2019

\begin{abstract}
Cocoa pod husk has not been used optimally by farmers, most of cocoa pod husk will discarded around the cacao tree or collected in one hole and then piled with soil. Cocoa pod husk waste can be used optimally by extracting polyphenol compounds which are used as natural antioxidant ingredients. This research aimed to determine the effect of particle size and maceration time on cocoa pod husk extract as a source of antioxidant and determine the best particle size and maceration time to produce cocoa pod husk extract as a source of antioxidants. This research used factorial randomized block design with two factors. Factor 1 is a particle size consisting of 40, 60, and 80 mesh. Factor 2 is maceration time consisting of 24, 36, and 48 hours. The data were analyzed by analysis of variance and then it will be proceed with tukey test. The results showed that particle size and maceration time affected yield, total phenolic and antioxidant capacity of cocoa pod husk extract, while the interaction was affected on total phenolic and antioxidant capacity but had no effect on yield of cocoa pod husk extract. The best treatment to produce cocoa pod husk extract as a source of antioxidants 80 mesh particle size and maceration time for 48 hours, with a yield value of $5.22 \pm 0.05$ percent, a total phenolic of $148.09 \pm$ $0.00 \mathrm{mg} \mathrm{GAE} / \mathrm{g}$ and antioxidant capacity of $118.71 \pm 0.13 \mathrm{mg} \mathrm{GAEAC} / \mathrm{g}$.
\end{abstract}

Keywords: cocoa pod husk, extraction, antioxidants, particle size, maceration time

\footnotetext{
*Korespondensi Penulis:

Email : gandaputra@unud.ac.id
} 


\section{PENDAHULUAN}

Indonesia merupakan penghasil kakao terbesar ketiga di dunia, setiap tahun permintaan biji kakao semakin meningkat, yang mengakibatkan meningkatnya kulit buah kakao yang terbuang. Menurut penelitian Sartini et al. (2007), kulit buah kakao dapat dijadikan salah satu sumber polifenol yang memiliki sifat antioksidan. Antioksidan adalah melekul yang mampu menghambat atau mencegah proses oksidasi melekul lain. Komponen fenolik kakao, utamanya flavonoid, mempunyai potensi bahan antioksidan alami (Sartini et a., 2017).

Ukuran partikel adalah salah satu faktor yang dapat mempengaruhi proses ekstraksi. Perbedaan ukuran partikel dapat dihasilkan melalui proses pengecilan ukuran bahan yang bertujuan untuk memecah membran sel pada bahan sehingga senyawa yang ada dalam sel akan mudah terlarut dalam pelarutnya. Menurut penelitian Norra et al. (2017), penggunaan ukuran partikel $0,25 \mathrm{~mm}$ atau 60 mesh menunjukkan nilai total fenol dan aktivitas antioksidan terbesar pada ekstrak rumput laut (Sargassum sp) yaitu 1,1972 mg GAE/g ekstrak dengan persen inhibisi 60,65 persen. Makanjuola (2017) melaporkan penggunaan ukuran partikel 40 mesh merupakan perlakuan terbaik untuk menghasilkan ekstrak cair dari teh, jahe, dan teh jahe dengan kandungan senyawa fenolik berturut-turut sebesar $685,44 \pm 175,283,58 \pm 19$, dan 483,02 \pm 176 mg GAE/L.

Selain ukuran partikel bahan, waktu maserasi juga merupakan salah satu faktor yang dapat mempengaruhi proses ekstraksi. Waktu maserasi yang tepat dapat menghasilkan senyawa yang optimal. Jika waktu yang digunakan terlalu singkat dapat mengakibatkan tidak semua senyawa terlarut kedalam pelarut yang digunakan dan jika waktu maserasi yang digunakan melebihi batas optimum tidak akan mengakibatkan peningkatan berat flavonoid terekstrak karena jumlah pelarut dalam zat terlarut telah jenuh. Dalam penelitian Amelinda et al. (2018), mengenai pengaruh waktu maserasi terhadap aktivitas antioksidan ekstrak rimpang temulawak, didapatkan hasil optimal dengan waktu maserasi selama 24 jam yang memperoleh total fenolik sebesar 205,86 mg GAE/g dan aktivitas antioksidan sebesar 84,45 persen. Selain itu dalam penelitian Suryani (2012) mengenai optimasi metode ekstraksi fenol dari rimpang jahe emprit didapatkan hasil optimal waktu ekstraksi selama 36 jam yang memperoleh ekstrak jahe dengan kadar fenol $371,12 \mathrm{mg} / \mathrm{g}$. Waktu maserasi daun belimbing wuluh optimal diperoleh dengan menggunakan 10 gram sampel, volume pelarut $250 \mathrm{~mL}$ atau perbandingan bahan dengan pelarut 1:25 dengan waktu maserasi selama 48 jam yang memperoleh berat flavonoid terekstrak sebanyak 72,31 mg (Yulianingtyas dan Bambang, 2016).

Berdasarkan hal-hal tersebut diatas, perlu dilakukan penelitian mengenai ukuran partikel dan waktu maserasi pada ekstraksi kulit buah kakao. Penelitian ini bertujuan untuk mengetahui pengaruh ukuran partikel dan waktu maserasi terhadap karakteristik ekstrak kulit buah kakao sebagai sumber antioksidan serta menentukan ukuran partikel dan waktu maserasi terbaik untuk menghasilkan ekstrak kulit buah kakao sebagai sumber antioksidan.

\section{METODE PENELITIAN}

\section{Tempat dan Waktu Pelaksanaan}

Penelitian ini dilaksanakan di Laboratorium Rekayasa Proses dan Pengendalian Mutu, Fakultas Teknologi Pertanian, Universitas Udayana. Waktu pelaksanaan penelitian dilakukan pada bulan Juni - September 2019. 


\section{Alat dan Bahan Penelitian}

Peralatan yang digunakan dalam penelitian ini adalah ayakan 40 mesh (Retsch), ayakan 60 mesh (Retsch), ayakan 80 mesh (Retsch), pemarutan, pisau, blender (Philips), timbangan analitik (Shimadzu), aluminium foil, tisu, kertas saring kasar, kertas saring Whatman no 1, rotary evaporator (Janke \& Kukel RV 06 - ML), sentrifugasi (Damon IEC Centrifuge), spektrofotometer UV-Vis (Thermo scientific), pipet volume (Iwaki), pipet tetes, pipet mikro (Socorex), gelas beker (Iwaki), gelas ukur (Iwaki), labu ukur (Behrotest), corong kaca (Pyrex), erlenmeyer (Herma), tabung reaksi (Iwaki), vortex mixer (Maxi mix II).

Bahan yang digunakan pada penelitian ini adalah kulit buah kakao jenis lindak dengan kriteria kulit berwarna kuning dan buah yang sudah berumur 4,5-6 bulan. Kulit buah kakao yang digunakan diambil dari perkebunan yang berada di Dusun Semseman, Desa Sangkan Gunung, Kecamatan Sidemen, Kabupaten Karangasem, Bali. Bahan kimia yang digunakan adalah etanol teknis 96 persen (Bratachem), metanol pa 85 persen (Merck) dan metanol pa 99,9 persen (Merck), folinCiocalteu (Merck), $\mathrm{Na}_{2} \mathrm{CO}_{3}$ (Merck), aquades (One $\mathrm{Med}$ ), asam galat (Sigma-aldrich), kristal DPPH (Himedia).

\section{Rancangan Percobaan}

Rancangan percobaan pada penelitian

ini menggunakan Rancangan Acak Kelompok faktorial dengan dua faktor. Faktor pertama adalah ukuran partikel yang terdiri dari 3 taraf yaitu: A1 (40 mesh), A2 (60 mesh) dan A3 (80 mesh). Faktor yang kedua adalah waktu maserasi yang terdiri dari tiga taraf yaitu: B1 (24 jam), B2 (36 jam) dan B3 (48 jam). Berdasarkan faktor tersebut diperoleh 9 kombinasi perlakuan. Masingmasing perlakuan dikelompokkan menjadi dua kelompok berdasarkan waktu pelaksanaannya, sehingga diperoleh 18 unit percobaan. Data yang didapatkan di analisa dengan analisis varian (ANOVA) kemudian dilanjutkan dengan uji beda nyata jujur menggunakan software Minitab 17. Untuk menentukan perlakuan terbaik dengan menggunakan semua parameter yang diukur dilakukan dengan uji efektifitas (de Garmo et al. 1984).

\section{Pelaksanaan Penelitian \\ Pembuatan Bubuk Kulit Buah Kakao}

Kulit buah kakao dicuci bersih dan diparut kemudian dikeringkan dengan menggunakan sinar matahari (Suhu $30 \pm 2{ }^{0} \mathrm{C}$ ) dan ditutup dengan kain berwarna hitam untuk mengurangi reaksi oksidasi pada senyawa polifenol. Pengeringan dilakukan selama \pm 7 hari sampai bahan mudah dipatahkan, kadar air kulit buah kakao 7 persen. Selanjutnya dihaluskan dengan menggunakan blender dan diayak sesuai dengan perlakuan. Pengayakan dilakukan dengan mengayak bubuk kulit buah kakao dengan ayakan 80 mesh, bubuk yang tidak lolos ayakan 80 mesh dilanjutkan dengan ayakan 60 mesh, bubuk yang tidak lolos ayakan 60 mesh diayak kembali menggunakan ayakan 40 mesh sehingga diperoleh bubuk kulit buah kakao dengan ukuran partikel sesuai dengan perlakuan.

\section{Ekstraksi}

Bubuk kulit buah kakao ukuran partikel 40, 60, dan 80 mesh masing-masing ditimbang sebanyak 30 gram dan ditambahkan larutan etanol 96 persen sebanyak $300 \mathrm{ml}$ (perbandingan bahan dengan pelarut adalah 1:10) (Amelinda et al. 2018). Bubuk kulit buah kakao diekstrak menggunakan metode maserasi dengan waktu 24, 36, dan 48 jam. Pada saat proses maserasi dilakukan penggojogan setiap 6 jam selama 5 menit dengan cara manual sehingga didapat ekstrak bercampur pelarut. Proses 
maserasi dilakukan pada botol berwarna gelap dengan kondisi tertutup rapat pada suhu ruang $\left(28-29^{\circ} \mathrm{C}\right)$. Setelah proses maserasi ekstrak bercampur pelarut disaring dengan menggunakan kertas saring kasar kemudian dilanjutkan dengan kertas saring Whatman No 1 selanjutnya filtrat diuapkan dengan menggunakan vacuum rotary evaporator dengan suhu $40^{\circ} \mathrm{C}$, tekanan 100 mBar dan kecepatan 100 rpm sampai tidak ada pelarut yang menetes sehingga diperoleh hasil berupa ekstrak kental. Ekstrak kental yang didapat selanjutnya ditimbang untuk menentukan rendemen ekstraknya kemudian ditempatkan didalam botol.

\section{Variabel yang Diamati}

Variabel yang diamati pada penelitian ini adalah rendemen ekstrak (Sudarmadji et al.1989), total fenol (Sakanaka et al. 2003), dan kapasitas antioksidan dengan metode diphenyl picryl hidrazil (DPPH) (Blois ,1958).

\section{Rendemen Ekstrak (Sudarmadji et al. 1989)}

Rendemen merupakan perbandingan antara jumlah produk akhir dengan jumlah bahan baku yang digunakan. Rendemen ekstrak kulit buah kakao dapat dihitung dengan menggunakan rumus sebagai berikut:

$$
\text { Rendemen }(\%)=\frac{\text { berat ekstrak }(\mathrm{g})}{\text { berat bubuk kulit buah kakao }(\mathrm{g})} \times 100 \%
$$

\section{Total Fenol (Sakanaka et al. 2003) Pembuatan Kurva Standar}

Kurva standar dibuat dengan menimbang 0,01 gram asam galat kemudian diencerkan menjadi $100 \mathrm{~mL}$ dengan aquades, dibuat seri pengenceran yang masing-masing sebanyak $5 \mathrm{~mL}$ dengan konsentrasi $0,10,20$, 40, 60, $80,100 \mathrm{mg} / \mathrm{L}$. Dari masing-masing standar dipipet sebanyak $400 \mu \mathrm{L}$ ditempatkan pada tabung reaksi, ditambahkan $400 \mu \mathrm{L}$ reagen Folin- Ciocalteu, divortek dan diinkubasi selama 6 menit sebelum ditambahkan 4,2 mL larutan sodium karbonat 5 persen. Sampel divortek dan diinkubasi selama 90 menit pada suhu ruang kemudian dibaca nilai absorbansi pada panjang gelombang $760 \mathrm{~nm}$.

\section{Analisis Sampel}

Sampel ditimbang sekitar $0,01 \mathrm{~g}$ kemudian diekstrak dengan $5 \mathrm{~mL}$ metanol 85 persen, dihomogenkan dan disentrifus 3000 rpm selama 15 menit, hingga diperoleh supernatan. Supernatan disaring hingga diperoleh filtrat. Filtrat diencerkan sampai volume $5 \mathrm{~mL}$ dalam labu ukur. Filtrat dipipet $50 \mu \mathrm{L}$ kemudian ditambahkan $350 \mu \mathrm{L}$ metanol, ditempatkan pada tabung reaksi, ditambahkan $400 \mu \mathrm{L}$ reagen FolinCiocalteu, divortek sehingga homogen dan didiamkan 6 menit sebelum ditambahkan 4,2 $\mathrm{mL}$ larutan sodium karbonat 5 persen. Sampel diinkubasi 90 menit pada suhu ruang sebelum dibaca absorbansinya pada panjang gelombang $760 \mathrm{~nm}$.

Perhitungan total fenol menggunakan rumus persamaan regresi $\mathrm{y}=\mathrm{ax}+\mathrm{b}$. yaitu $\mathrm{y}$ menunjukkan absorbansi, $\mathrm{x}$ menunjukkan konsentrasi asam galat, a menunjukkan intersep dan $b$ adalah konstanta. Total kandungan fenol pada ekstrak ditunjukkan sebagai $\mathrm{mg}$ ekuivalen asam galat/g sampel. Total fenol dapat dihitung dengan menggunakan rumus :

$$
\text { Total Fenol }\left(\frac{\mathrm{mg} \mathrm{GAE}}{\mathrm{g}}\right)=\frac{\mathrm{X}\left(\frac{\mathrm{mg}}{\mathrm{mL}}\right) \times \text { Volume Larutan }(\mathrm{mL})}{\text { sampel }(\mathrm{g})} \times \mathrm{FP}
$$


Keterangan :

$\mathrm{X}=$ Konsentrasi yang diperoleh dari persamaan regresi linier kurva standar asam galat $\left(\frac{\mathrm{mg}}{\mathrm{mL}}\right)$

$\mathrm{FP}=$ Faktor pengencer

\section{Kapasitas Antioksidan Dengan Metode DPPH (Blois , 1958) \\ Pembuatan Kurva Standar}

Kurva standar dibuat dengan menimbang 0,01 gram asam galat kemudian diencerkan dengan aquades menjadi $100 \mathrm{~mL}$, dibuat seri pengenceran yang masing-masing sebanyak $5 \mathrm{~mL}$ dengan konsentrasi $0,5,10$, 15, 20, $25 \mathrm{ppm}$. Dari masing-masing standar dipipet $500 \mu \mathrm{L}$ ditempatkan pada tabung reaksi dan ditambahkan 3,5 $\mathrm{ml} \mathrm{DPPH}, 0,1$ $\mathrm{mM}(0,004$ gram dalam pelarut metanol 99,9 persen $100 \mathrm{~mL}$ ) kemudian divortek. Selanjutnya diinkubasi selama 30 menit dan dibaca nilai absorbansi pada panjang gelombang $517 \mathrm{~nm}$.

\section{Analisis Sampel}

Sampel ditimbang sekitar $0,01 \mathrm{~g}$ kemudian diencerkan dengan metanol 99,9 persen sampai volume $5 \mathrm{~mL}$ dalam labu ukur, divortek dan disentrifugasi 3000 rpm selama 15 menit, hingga diperoleh supernatan. Supernatan disaring hingga diperoleh filtrat. Filtrat dipipet $50 \mu \mathrm{L}$ kemudian ditambahkan $450 \mu \mathrm{L}$ metanol, ditempatkan pada tabung reaksi, ditambahkan $3.5 \mathrm{~mL}$ DPPH $0,1 \mathrm{mM}$ $(0,004$ gram dalam $100 \mathrm{~mL}$ pelarut metanol 99,9 persen) kemudian divortek. Selanjutnya diinkubasi selama 30 menit dan diukur absorbansinya pada panjang gelombang 517 nm.

Kapasitas antioksidan dihitung dengan menggunakan rumus persamaan regresi linier $\mathrm{y}=\mathrm{ax}+\mathrm{b}$ dimana $\mathrm{y}$ menunjukkan absorbansi, $\mathrm{x}$ menunjukkan konsentrasi asam galat, a menunjukkan intersep dan $\mathrm{b}$ adalah konstanta. Aktivitas antioksidan dapat dihitung dengan menggunakan rumus:

\section{Keterangan :}

$$
\text { Kapasitas Antioksidan }\left(\frac{\mathrm{mg} \mathrm{GAEAC}}{\mathrm{g}}\right)=\frac{\mathrm{X}\left(\frac{\mathrm{mg}}{\mathrm{mL}}\right) \times \text { Volume Larutan }(\mathrm{mL})}{\text { sampel }(\mathrm{g})} \times \mathrm{FP}
$$

$\mathrm{X}=$ Konsentrasi yang diperoleh dari persamaan regresi linier kurva standar asam galat $\left(\frac{\mathrm{mg}}{\mathrm{mL}}\right)$

$\mathrm{FP}=$ Faktor pengencer

\section{HASIL DAN PEMBAHASAN}

\section{Rendemen}

Hasil analisis ragam menunjukkan perlakuan ukuran partikel dan waktu maserasi berpengaruh sangat nyata $(\mathrm{P} \leq 0,01)$, sedangkan interaksi kedua perlakuan berpengaruh tidak nyata $(\mathrm{P} \geq 0,05)$ terhadap rendemen ekstrak kulit buah kakao. Nilai rata-rata rendemen ekstrak kulit buah kakao dapat dilihat pada Tabel 1.

Tabel 1. Nilai rendemen (\%) ekstrak kulit buah kakao pada perlakuan ukuran partikel dan waktu maserasi.

\begin{tabular}{ccccc}
\hline \multirow{2}{*}{ Ukuran partikel (mesh) } & \multicolumn{3}{c}{ Waktu maserasi (jam) } & \multirow{2}{*}{ Rata-rata } \\
\cline { 2 - 4 } & 24 & 36 & 48 & $3,07 \pm 0,28^{\mathrm{c}}$ \\
\hline 40 & 2,82 & 3,02 & 3,37 & $3,29 \pm 0,27^{\mathrm{b}}$ \\
60 & 3,00 & 3,35 & 3,53 & $4,82 \pm 0,33^{\mathrm{a}}$ \\
\hline Rata-rata & 4,53 & 4,69 & 5,22 & $4,04 \pm 0,92^{\mathrm{a}}$ \\
\end{tabular}

Keterangan: huruf yang berbeda di belakang nilai rata-rata pada baris dan kolom yang sama menunjukkan perbedaan yang sangat nyata pada taraf kesalahan $5 \%(\mathrm{P} \leq 0,05)$ 
Tabel 1 menunjukkan bahwa nilai rata-rata rendemen ekstrak kulit buah kakao pada perlakuan ukuran partikel 80 mesh menghasilkan nilai tertinggi yaitu 4,82 $\pm 0,33$ persen sedangkan perlakuan ukuran partikel 40 mesh menghasilkan nilai terendah yaitu $3,07 \pm 0,28$ persen. Rata-rata rendemen mengalami peningkatan sesuai dengan semakin kecilnya ukuran partikel yang digunakan. Ini menunjukan bahwa semakin kecil ukuran partikel yang digunakan maka semakin banyak membran sel bahan yang pecah. Membran sel bahan yang pecah memudahkan pelarut untuk menarik senyawa dari dalam sel sehingga proses difusi senyawa menjadi lebih mudah. Maulida dan Guntarti (2015) juga menyatakan bahwa semakin kecil ukuran partikel maka akan mempermudah kontak pelarut dengan padatan sehingga mempercepat senyawa berdifusi keluar sel yang menyebabkan rendemen semakin banyak. Hasil ini juga didukung oleh penelitian Sembiring et al. (2008), tentang pengaruh kehalusan bahan dan lama ekstraksi terhadap mutu ekstrak temulawak yang menunjukan bahwa semakin halus bahan yang digunakan semakin tinggi rendemen

Tabel 2. Nilai rata-rata total fenolik (mg GAE/g) ekstrak kulit buah kakao pada perlakuan ukuran partikel dan waktu maserasi.

\begin{tabular}{cccc}
\hline \multirow{2}{*}{ Ukuran partikel (mesh) } & \multicolumn{3}{c}{ Waktu maserasi (jam) } \\
\cline { 2 - 4 } & 24 & 36 & 48 \\
\hline 40 & $67,99 \pm 0,27^{\mathrm{e}}$ & $78,63 \pm 1,41^{\mathrm{d}}$ & $133,74 \pm 0,47^{\mathrm{b}}$ \\
60 & $70,04 \pm 0,95^{\mathrm{e}}$ & $88,75 \pm 0,73^{\mathrm{c}}$ & $135,39 \pm 4,12^{\mathrm{b}}$ \\
80 & $73,29 \pm 0,54^{\text {de }}$ & $130,14 \pm 3,28^{\mathrm{b}}$ & $148,09 \pm 0,00^{\mathrm{a}}$ \\
\hline
\end{tabular}

Keterangan: huruf yang berbeda di belakang nilai rata-rata menunjukkan perbedaan yang nyata pada taraf kesalahan $5 \%$ $(\mathrm{P} \leq 0,05)$

Tabel 2 menunjukkan total fenolik ekstrak kulit buah kakao tertinggi diperoleh dari perlakuan ukuran partikel 80 mesh dan waktu maserasi 48 jam yaitu sebesar $148,09 \pm 0,00 \mathrm{mg}$ GAE$/ \mathrm{g}$ dan hasil total fenolik terendah diperoleh dari perlakuan ukuran partikel 40 mesh dan waktu maserasi 24 jam yaitu sebesar $67,99 \pm 0,27 \mathrm{mg}$ GAE/g. Pada penelitian ini ukuran partikel 80 mesh yang dihasilkan, karena ukuran bahan yang sesuai akan menjadikan proses ekstraksi berlangsung dengan baik dan tidak memakan waktu yang lama.

Perlakuan waktu maserasi ekstrak kulit buah kakao menunjukkan nilai rendemen tertinggi diperoleh dari perlakuan waktu maserasi selama 48 jam yaitu 4,04 $\pm 0,92$ persen, dan terendah diperoleh dari waktu maserasi 24 jam yaitu $3,45 \pm 0,85$ persen. Hasil tersebut menunjukkan semakin lama waktu maserasi yang digunakan menghasilkan kenaikan nilai rendemen, hal ini dikarenakan tersedianya waktu yang cukup untuk pelarut menarik senyawa dari dalam sel sehingga semakin meningkat sampai pada titik jenuh dari pelarut.

\section{Total Fenolik}

Hasil analisis ragam menunjukkan perlakuan ukuran partikel dan waktu maserasi serta interaksi kedua perlakuan berpengaruh sangat nyata $(P \leq 0,01)$ terhadap total fenolik ekstrak kulit buah kakao. Nilai rata-rata total fenolik ekstrak kulit buah kakao dapat dilihat pada Tabel 2. 
banyaknya membran sel yang pecah pada bahan mempermudah pelarut untuk menarik senyawa fenolik dari dalam sel dan mempermudah proses difusi senyawa fenolik ke pelarut sehingga dihasilkan ekstrak yang lebih banyak.

Waktu maserasi yang semakin lama menghasilkan kenaikan nilai total fenolik, dikarenakan tersedianya waktu yang cukup untuk pelarut menarik senyawa fenolik dari dalam sel sampai pelarut jenuh dengan ekstrak. Hal ini juga sesuai dengan penelitian (Yulianingtyas dan Bambang, 2016) mengenai waktu maserasi daun belimbing wuluh didapatkan hasil optimum dengan menggunakan waktu maserasi selama 48 jam dan penelitian Firdausni et al. (2011), mengenai potensi pigmen kulit kayu manis pada minuman jahe instan sebagai minuman fungsional bahwa lama maserasi 48 menghasilkan total fenol tertinggi.

\section{Kapasitas Antioksidan}

Hasil analisis ragam menunjukkan bahwa perlakuan ukuran partikel dan waktu maserasi serta interaksinya berpengaruh sangat nyata $(\mathrm{P} \leq 0,01)$ terhadap kapasitas antioksidan ekstrak kulit buah kakao. Nilai rata-rata kapasitas antiksidan (mg GAEAC/g) ekstrak kulit buah kakao dapat dilihat pada Tabel 3.

Tabel 3. Nilai rata-rata kapasitas antioksidan (mg GAEAC/g) ekstrak kulit buah kakao pada perlakuan ukuran partikel dan waktu maserasi.

\begin{tabular}{cccc}
\hline \multirow{2}{*}{ Ukuran partikel (mesh) } & \multicolumn{3}{c}{ Waktu maserasi (jam) } \\
\cline { 2 - 4 } & 24 & 36 & 48 \\
\hline 40 & $52,82 \pm 5,43^{\mathrm{e}}$ & $103,00 \pm 0,63^{\mathrm{b}}$ & $106,39 \pm 0,63^{\mathrm{b}}$ \\
60 & $61,93 \pm 0,63^{\mathrm{d}}$ & $103,89 \pm 0,38^{\mathrm{b}}$ & $110,32 \pm 0,38^{\mathrm{b}}$ \\
80 & $83,00 \pm 0,88^{\mathrm{c}}$ & $105,68 \pm 0,88^{\mathrm{b}}$ & $118,71 \pm 0,13^{\mathrm{a}}$ \\
\hline
\end{tabular}

Keterangan: huruf yang berbeda di belakang nilai rata-rata menunjukkan perbedaan yang nyata pada taraf kesalahan $5 \%$ $(\mathrm{P} \leq 0,05)$

Tabel 3 menunjukkan kapasitas antioksidan tertinggi diperoleh dari perlakuan ukuran partikel 80 mesh dan waktu maserasi selama 48 jam yaitu sebesar $118,71 \pm 0,13 \mathrm{mg}$ GAEAC/g dan kapasitas antioksidan terendah diperoleh dari perlakuan ukuran partikel 40 mesh dan waktu maserasi selama 24 jam yaitu sebesar 52,82 $\pm 5,43 \mathrm{mg}$ GAEAC/ g. Kapasitas antioksidan yang dihasilkan dipengaruhi oleh senyawa polifenol yang terdapat pada kulit buah kakao, semakin tinggi kandungan senyawa polifenol pada kulit buah kakao semakin tinggi juga kapasitas antioksidannya. Pada penelitian ini hasil total fenolik dan kapasitas antioksidan tertinggi dihasilkan dari perlakuan ukuran partikel 80 mesh dan waktu maserasi selama 48 jam dengan nilai total fenolik yaitu $148,09 \pm 0,00 \mathrm{mg}$ GAE/g dan kapasitas antioksidan yaitu $118,71 \pm 0,13$ mg GAEAC/g dan nilai terendah dihasilkan dari perlakuan ukuran partikel 40 mesh dan waktu maserasi selama 24 jam dengan nilai total fenolik yaitu $67,99 \pm 0,27 \mathrm{mg} \mathrm{GAE} / \mathrm{g}$ dan nilai kapasitas antioksidan yaitu 52,82 $\pm 5,43$ mg GAEAC/ g . Hasil ini juga sesuai dengan laporan Towaha (2014) bahwa, kapasitas antioksidan biji kakao dan produk turunannya dengan jumlah total polifenol yang dimiliki mempunyai korelasi yang positif. Sehingga semakin tinggi kandungan polifenol maka akan semakin tinggi juga nilai kapasitas antioksidannya.

\section{Indeks Efektivitas}

Uji indeks efektivitas bertujuan untuk menentukan perlakuan terbaik untuk mendapatkan hasil ekstrak kulit buah kakao, dengan variabel yang diamati adalah rendemen, total fenolik dan kapasitas 
antioksidan. Hasil dari uji indeks efektivitas dapat dilihat pada Tabel 4.

Perlakuan dengan nilai hasil tertinggi ditetapkan sebagai perlakuan terbaik. Tabel 4 menunjukkan bahwa perlakuan terbaik dihasilkan dari ukuran partikel 80 mesh dan waktu maserasi selama 48 jam dengan nilai 1,00 untuk menghasilkan ekstrak kulit buah kakao sebagai sumber antioksidan.

Tabel 4. Hasil uji indeks efektivitas

\begin{tabular}{|c|c|c|c|c|c|}
\hline \multirow{2}{*}{\multicolumn{2}{|c|}{ Perlakuan }} & \multicolumn{3}{|c|}{ Variabel } & \multirow{2}{*}{ Jumlah } \\
\hline & & Rendemen & Total Fenolik & Kapasitas Antioksidan & \\
\hline \multirow{4}{*}{ A1B1 } & $\overline{(B V)}$ & 1,8 & 2,2 & 2,6 & 6,6 \\
\hline & $(\mathrm{BN})$ & 0,27 & 0,33 & 0,39 & 1,00 \\
\hline & $\mathrm{Ne}$ & 0 & 0 & 0 & \\
\hline & $\mathrm{Nh}$ & 0 & 0 & 0 & 0 \\
\hline \multirow[t]{2}{*}{$\mathrm{A} 2 \mathrm{~B} 1$} & $\mathrm{Ne}$ & 0,08 & 0,03 & 0,14 & \\
\hline & $\mathrm{Nh}$ & 0,02 & 0,01 & 0,05 & 0,08 \\
\hline \multirow[t]{2}{*}{$\mathrm{A} 3 \mathrm{~B} 1$} & $\mathrm{Ne}$ & 0,72 & 0,07 & 0,46 & \\
\hline & $\mathrm{Nh}$ & 0,2 & 0,02 & 0,18 & 0,4 \\
\hline \multirow[t]{2}{*}{ A1B2 } & $\mathrm{Ne}$ & 0,08 & 0,13 & 0,76 & \\
\hline & $\mathrm{Nh}$ & 0,02 & 0,04 & 0,3 & 0,37 \\
\hline \multirow[t]{2}{*}{$\mathrm{A} 2 \mathrm{~B} 2$} & $\mathrm{Ne}$ & 0,22 & 0,26 & 0,78 & \\
\hline & $\mathrm{Nh}$ & 0,06 & 0,09 & 0,31 & 0,45 \\
\hline \multirow[t]{2}{*}{$\mathrm{A} 3 \mathrm{~B} 2$} & $\mathrm{Ne}$ & 0,78 & 0,78 & 0,8 & \\
\hline & $\mathrm{Nh}$ & 0,21 & 0,26 & 0,32 & 0,79 \\
\hline \multirow[t]{2}{*}{ A1B3 } & $\mathrm{Ne}$ & 0,23 & 0,82 & 0,81 & \\
\hline & $\mathrm{Nh}$ & 0,06 & 0,27 & 0,32 & 0,66 \\
\hline \multirow[t]{2}{*}{ A2B3 } & $\mathrm{Ne}$ & 0,3 & 0,84 & 0,87 & \\
\hline & $\mathrm{Nh}$ & 0,08 & 0,28 & 0,34 & 0,7 \\
\hline \multirow[t]{2}{*}{ A3B3 } & $\mathrm{Ne}$ & 1,00 & 1,00 & 1,00 & \\
\hline & $\mathrm{Nh}$ & 0,27 & 0,33 & 0,39 & 1,00 \\
\hline
\end{tabular}

\section{KESIMPULAN DAN SARAN}

\section{Kesimpulan}

Berdasarkan penelitian yang telah dilakukan maka dapat disimpulkan beberapa hal sebagai berikut:

1. Ukuran partikel dan waktu maserasi berpengaruh terhadap rendemen, total fenolik dan kapasitas antioksidan ekstrak kulit buah kakao, sedangkan untuk interaksi berpengaruh terhadap total fenolik dan kapasitas antioksidan tetapi tidak berpengaruh untuk rendemen ekstrak kulit buah kakao.

2. Perlakuan terbaik untuk menghasilkan ekstrak kulit buah kakao sebagai sumber antioksidan adalah ukuran partikel 80 mesh dan waktu maserasi selama 48 jam, dengan karakteristik ekstrak yaitu nilai rendemen sebesar 5,22 $\pm 0,05$ persen, total fenolik sebesar $148,09 \pm 0,00 \mathrm{mg}$ GAE/g dan kapasitas antioksidan sebesar $118,71 \pm 0,13 \mathrm{mg} \mathrm{GAEAC} / \mathrm{g}$.

\section{Saran}

Berdasarkan hasil penelitian ini dapat disarankan beberapa hal sebagai berikut :

1. Berdasarkan penelitian yang sudah dilakukan untuk mengasilkan ekstrak kulit buah kakao sebagai sumber antioksidan, disarankan menggunakan 
perlakuan ukuran partikel 80 mesh dan waktu maserasi selama 48 jam.

2. Perlu dilakukan penelitian lebih lanjut mengenai ukuran partikel yang lebih halus dan waktu maserasi yang lebih lama serta pengaplikasian ekstrak kulit buah kakao pada suatu produk.

\section{DAFTAR PUSTAKA}

Ansel, H.C. 1989. Pengantar Bentuk Sediaan Farmasi. UI Press, Jakarta.

Antari, N.M.R.O., N.M. Wartini., dan S. Mulyani. 2015. Pengaruh ukuran partikel dan lama ekstraksi terhadap karakteristik ekstrak warna alami buah pandan (Pandanus tectorius). Jurnal Rekayasa dan Manajemen Agroindustri. 3(4):30-40.

Amelinda, E., I.W.R. Widarta., dan L.P.T. Darmayanti. 2018. Pengaruh waktu maserasi terhadap aktivitas antioksidan ekstrak rimpang temulawak (Curcuma xanthorriza Roxb.). Jurnal Ilmu dan Teknologi Pangan. 7(4):165-174.

Basito. 2011. Efektivitas penambahan etanol $95 \%$ dengan variasi asam dalam proses ekstraksi pigmen antosianin kulit manggis (Garcinia mangostan L.). Jurnal Teknologi Hasil Pertanian. IV(2): 84-93.

Blois, M. S. 1958. Antioxidant determinations by the use of a stable free radical. Nature .181 (4617): 11991200 .

Budiyanto, A., dan Yulianingsih. 2008. Pengaruh suhu dan waktu ekstraksi terhadap karakter pektin dari ampas jeruk siam (Citrus nobilis L.) Jurnal Pascapanen. 5(2): 37-44.

Cahyadi, W. 2006. Analisis dan Aspek Kesehatan Bahan Tambahan Pangan. Bumi Aksara, Jakarta.
Cikita, I., I. H. Hasibuan., dan R. Hasibuan. 2016. Pemanfaatan flavonoid ekstrak daun katuk ( Sauropus androgynous L.) sebagai antioksidan pada minyak kelapa. Jurnal Teknik Kimia. USU.5(1):45-51.

Darwis, D. 2000. Teknik Dasar Laboratorium dalam Penelitian Senyawa Bahan Alam Hayati, Workshop Pengembangan Sumber Daya Manusia dalam Bidang Kimia Organik Bahan Alam Hayati. FMIPA, Universitas Andalas, Padang.

de Garmo, E. P., W. G. Sullivan dan C. R. Canada. 1984. Engineering Economy. Macmilan Publisher, New York.

Darma, G., Lucyana dan H.G. Pohan. 1991. Pengaruh jenis pelarut serta ukuran partikel terhadap rendemen dan kadar piperin oleoresin limbah lada putih (Piper nigrum Linn). Journal of Agrobased Industry. 5(1):24-27.

Erna, R.M. 1998. Ekstrak Kulit Buah Kakao (Theobroma cacao L.). Skripsi. Tidak dipublikasikan. Fakultas Teknologi Pertanian, IPB, Bogor.

Erniati. 2007. Efek Konsumsi Minuman Bubuk Kakao Bebas Lemak terhadap Sifat Antioksidatif dan Prolifertif Limfosit Manusia. Tesis. Tidak dipublikasikan. Institut Pertanian Bogor, Bogor.

Firdausni, Failisnur dan H. Diza. 2011. Potensi pigmen cassiavera pada minuman jahe instan sebagai minuman fungsional. Jurnal Litbang Industri. $1(1): 15-2$.

Firdausil, A.B, Narsriati, A. Yani. 2008. Teknologi Budidaya kakao. Balai Besar Pengkajian dan Pengembangan Teknologi Pertanian, Badan Peneliti dan Pengembangan Pertanian.

Genwali, G. R., P. P. Acharya., and M. Rajbhandari. 2013. Isolation of gallic 
acid and estimation of total phenolic content in some medicinal plants and their antioxidant activity. Nepal Journal of Science and Technology. 14(1):95102.

Harborne, J. B. 1987. Metode Fitokimia Penuntun Cara Modern Menganalisis Tumbuhan. ITB, Bandung.

Inggrid, H.M. dan H. Santoso. 2014. Ekstraksi Antioksidan dan Senyawa Aktif dari Buah Kiwi (Actinidia deliciosa). Lembaga Penelitian dan Pengabdian kepada Masyarakat, Universitas Katolik Parahyangan, Bandung.

Kiswandono, A. A. 2011. Skrining senyawa kimia dan pengaruh metode maserasi dan refluks pada biji kelor (Moringa oleifera Lam.) terhadap rendemen ekstrak yang dihasilkan. Jurnal Sains Natural Universitas Nusa Bangsa. 1(2): 126-134.

Keenan. 1986. Ilmu Kimia untuk Universitas Edisi VI. Erlangga, Jakarta.

Karyadi, E. 1997. Antioksidan resep awet muda dan umur panjang. Pharmacon. 6(2):51-56.

Makanjuola, S.A. 2017. Influences of particle size and extraction solvent on antioxidant properties of extracts of tea, ginger, and tea-ginger blend. Food Science and Nutrition. 5:1179-1185.

Loppies, J.E., dan M. Yumas. 2014. Ekstraksi komponen aktif kulit buah kakao dan pemanfaatannya sebagai bahan pengawet alami pada produk makanan. Jurnal Industri Hasil Perkebunan. 9 (1): 59-68.

Maulida, R., and A. Guntarti. 2015. The influence of particle size of black rice (Oryza sativa L.) on extract yield and total anthocyanin content. Pharmaciana. 5(1): 9-16
Noviantari, N.P., L. Suhendra dan N. M. Wartini. 2017. Pengaruh ukuran partikel bubuk dan konsentrasi pelarut aseton terhadap karakteristik ekstrak warna (Sargassum polycystum). Jurnal Rekayasa dan Manjemen Agroindustri. 5(3): 102-112.

Nofitahesti, I. 2014. Kandungan Polifenol Serta Potensi Kulit Buah dan Kulit Biji Kakao (Theobroma cacao L.) sebagai Antioksidan. Skripsi. Tidak dipublikasikan. Fakultas Biologi, Universitas Gadjah Mada, Yogyakarta.

Nwabanne, J.T. 2012. Kinetics and thermdunamics study of oil extraction from fluted pumpkin seed. International Journal of Mutridiciplinarty Sciences and Engginering. 3(6):11-15.

Othman, A., A.M. Jalil., K.K . Weng., A. Ismail., N.A. Ghani., and I. Adenan. 2010. Epicatechin content and antioxidant capacity of cocoa beans from four different countries. Africa Journal of Biotech. 9(7):1052-1059.

Pandey, K.B. and S.I. Rivzi. 2009. Plant polyphenols as dietary anioxidant in human health and disease. Journal Oxidative Medicine and Cellular Longevity 2(5):270-278.

Prihanda, R. 2008. Energi Hijau. Penebar Swadaya, Jakatra.

Purseglove, J. W., E. G. Brown, C.L. Green., and S. R. J. Robins .1981. Spices. Vol. 2. Longman, New York.

Roesmanto, J. 1991. Kakao Kajian Sosial Ekonomi. Aditya Media, Yogyakarta.

Sartini., M. N. Djide., dan N. Duma. 2012. Pemanfaatan limbah kulit buah kakao sebagai sumber bahan aktif untuk sediaan farmasi. Jurnal Industri Hasil Perkebunan. 7(2): 69-73. 
Sartini., G. Alam., dan M.N. Djide . 2007. Eksraksi komponen bioaktif dari limbah kulit buah kakao dan pengaruhnya terhadap aktivitas antioksidan dan antimikroba. Jurnal Farmasi Indonesia. 5(1):1-7.

Sartini, R. dan M. A. Ismail. 2017. Pengaruh pra perlakuan sebelum pengeringan sinar matahari dari kulit buah kakao terhadap kadar komponen fenolik dan ekstrak. Jurnal Biologi Makasar. 2(1):15-20.

Sembiring, B.B., Mamun., dan E. I. Ginting. 2008. Pengaruh kehalusan bahan dan lama ekstraksi terhadap mutu ekstrak temulawak. Bul Littro. 17(2):53-58.

Siregar, I. M. 1996. Catatan-Catatan Mengenai Pengolahan Biji Kakao. USU Press, Medan.

Siregar, T.H.S., S. Riyadi., dan L. Nuraeni. 2009. Kakao (Pembudidayaan, Pengolahan, Pemasaran). Penebar Swadaya, Jakarta.

Sudarmadji, S., B. Haryono dan Suhardi. 1989. Prosedur Analisa untuk Bahan Makanan dan Pertanian. Liberty, Yogyakarta.

Susanty dan F. Bachmid. 2017. Perbandingan metode ekstraksi maserasi dan refluks terhadap kadar fenolik dari ekstrak tongkol jagung (Zea mays L.). Konversi. 5(2):87-93.

Suryani, L. 2012. Optimasi metode ekstraksi fenol dari rimpang jahe emprit (Zingiber officinalle Var. Rubrum). Jurnal AgriSains. 3(4):63-70.

Sutriani. 2008. Teknik Pemblajaran Fitokimia. Universitas Muhamadiyah, Semarang.

Supari, F. 1996. Radikal Bebas dan Patofisiologi Beberapa Penyakit. Kerjasama Pusat Studi Pangan dan Gizi
IPB dengan Kedutaan Perancis, Jakarta.

Tambun, R., H.P. Limbong., C. Pinem dan E. Manurung. 2016. Pengaruh ukuran partikel, waktu dan suhu padaekstraksi fenol dari lengkuas merah. Jurnal Teknik Kimia. 5(4): 53-56.

Tjitrosoepomo, M. 1998. Taksonomi Tumbuhan (Spermatophyta). Gadjah Mada University Press, Yogyakarta.

Towaha, J. 2014. Kandungan senyawa polifenol pada biji kakao dan kontribusinya terhadap kesehatan. Sirinov. 2(1): 1-16.

Triastiari, A dan Harijono.2019. Pengaruh pengeringan dan lama maserasi dengan pelarut ganda etanol dan heksana terhadap senyawa bioaktif kulit buah palem putri (Veitchia merillii). Jurnal Pangan dan Agroindustri. 7(1):17-28.

Treyball, R. E. 1980. Mass Transfer Operation, 3 th Edition. Mc Graw Hill Book Company Inc, New York.

Underwood, A., L. Ficia dan A.R. Day. 1990. Analisis Kimia Kuantitatif Edisi Kelima. Penerbit Erlangga, Jakarta.

Winarsi, H. 2007. Antioksidan Alami dan Radikal Bebas Potensi dan Aplikasinya Dalam Kesehatan. Kanisius, Yogyakarta.

Wollgast, J. dan E. Anklam. 2000. Review on polyphenols in Theobroma cacao changes in composition during the manufacture of chocolate and methodology for identification and quantification. Food Research International 33(2000): 423-447.

Yulianingtyas, A., dan B. Kusmantoro. 2016. Optimasi volume pelarut dan waktu maserasi pengambilan flavonoid daun belimbing wuluh (Averrhoa bilimbi L.). Jurnal Teknik Kimia. 10(2):58-64. 